Review

\title{
Effects of Biosolids and Manure Application on Microbial Water Quality in Rural Areas in the US
}

\section{Amira Oun ${ }^{1}$, Arun Kumar ${ }^{2}$, Timothy Harrigan ${ }^{3}$, Andreas Angelakis ${ }^{4}$ and Irene Xagoraraki ${ }^{1, *}$}

1 Department of Civil and Environmental Engineering, Michigan State University, East Lansing, 48824, USA; E-Mail: ounamira@msu.edu

2 Department of Civil Engineering, Indian Institute of Technology Delhi, New Delhi 110016, India; E-Mail: arunku@civil.iitd.ac.in

3 Department of Biosystems and Agricultural Engineering, Michigan State University, East Lansing, 48824, USA; E-Mail: harriga1@anr.msu.edu

4 National Agricultural Research Foundation, Iraklion 71307, Hellas, Greece; E-Mail: info@a-angelakis.gr

* Author to whom correspondence should be addressed; E-Mail: xagorara@msu.edu; Tel.: +1-517-353-8539.

External Editor: Miklas Scholz

Received: 30 July 2014; in revised form: 31 October 2014 / Accepted: 14 November 2014 /

Published: 28 November 2014

\begin{abstract}
Most of the waterborne disease outbreaks observed in North America are associated with rural drinking water systems. The majority of the reported waterborne outbreaks are related to microbial agents (parasites, bacteria and viruses). Rural areas are characterized by high livestock density and lack of advanced treatment systems for animal and human waste, and wastewater. Animal waste from livestock production facilities is often applied to land without prior treatment. Biosolids (treated municipal wastewater sludge) from large wastewater facilities in urban areas are often transported and applied to land in rural areas. This situation introduces a potential for risk of human exposure to waterborne contaminants such as human and zoonotic pathogens originating from manure, biosolids, and leaking septic systems. This paper focuses on waterborne outbreaks and sources of microbial pollution in rural areas in the US, characterization of the microbial load of biosolids and manure, association of biosolid and manure application with microbial contamination of surface and groundwater, risk assessment and best management practice for biosolids and manure application to protect water quality. Gaps in knowledge are identified, and recommendations to improve the water quality in the rural areas are discussed.
\end{abstract}


Keywords: best management practices; biosolids; manure; contamination of ground and surface waters; microbial source tracking; microorganisms; pathogens; risk assessment; rural systems; waterborne diseases; water quality

\section{Waterborne Outbreaks in Rural Areas in the US}

Most of the waterborne disease outbreaks worldwide and in North America are associated with rural drinking water systems. According to Craun et al. [1], in the United States during the 12 years period of 1991-2002, 207 waterborne disease outbreaks and 433,947 illnesses were reported; 42\% of these outbreaks occurred in non-community water systems, $22 \%$ occurred in individual systems such as private wells, and only $36 \%$ occurred in community systems. In most cases the drinking water supply in rural areas is provided by groundwater wells that in some cases are shallow. Between 1981 and 1998, $50 \%$ (210 of 417 ) of the reported waterborne disease outbreaks were linked to contaminated groundwater [2,3]. 696 outbreaks have been reported in the US between 1971 and 2000, of which 59\% were linked to groundwater [4].

Most of the reported waterborne diseases outbreaks in North America were related to microbial agents (parasites, bacteria and viruses), some to chemical agents, and some were of unknown etiology. For example, a survey by the Centers for Disease Control and Prevention (CDC) reported that one sixth (5 out of 30 cases) of drinking water-associated waterborne disease outbreaks during 2003-2004 were of unknown etiology because of a lack of available analytical methods [5]. The US EPA suspects that many of the outbreaks due to unidentified sources were caused by enteric viruses [6]. Zoonotic and human viruses are of particular interest because viruses are the smallest of all pathogens and their small size can facilitate transport through the soil. Viruses have low die-off rates and viral infections may lead to chronic health effects.

Runoff carrying manure-borne microbial pathogens have been implicated in some of the largest water and food borne outbreaks [7-9]; in contrast, it is important to state that there are no scientifically documented outbreaks or excess illnesses that have occurred from exposure to pathogens associated with treated biosolids [10]. An outbreak that occurred in a small farming community in Canada demonstrated that the potential of human infections caused by zoonotic pathogens (pathogens that may infect both animals and humans) has serious consequences [7,9]. More than 2300 people in the town of Walkerton, Ontario suffered gastrointestinal illness and seven died when the water supply was contaminated by manure pathogens from a nearby farm after more than five inches of rain fell over a five day period in May 2000 [7,9].

During March and April 1993 water contaminated with Cryptosporidium oocysts from Lake Michigan caused a massive waterborne outbreak of cryptosporidiosis among residents of Milwaukee, Wisconsin. The source of contaminated water was most likely runoff from rural areas during high rainfall. It was estimated that 403,000 residents living in a five-county area and numerous visitors to the city of Milwaukee were sick during this outbreak and 58 lost their lives [11].

In recreational waters, fecal contamination from bathers has been an important source of exposure. During 1971-2000, 259 outbreaks associated with recreational activities have been reported, 144 outbreaks (56\%) 
were associated with recreation in untreated natural water such as lakes and streams; the remaining of the recreational outbreaks occurred in treated water such as swimming pools [12]. Fecal contamination from bathers, septic tanks, runoff from agricultural areas, and other sources was identified as the important cause of outbreaks in untreated recreational waters. Zoonotic bacterial agents such as E. coli O157:H7 and O121:H19 caused $38 \%$ of the outbreaks associated with untreated natural recreational water $[1,12]$.

\section{Sources of Microbial Pollution in Rural Areas in the US}

The nexus between water quality and public health in the rural environment is complex. Non-point sources of contaminants are common and there is little monitoring of the system or the types of pollutants and emerging contaminant risks. Human and zoonotic pathogens and other microbial pollutants are a particular concern. Water quality research tends to focus on urban areas and sophisticated treatment systems. Water and waste management in rural areas is often minimal and water quality monitoring is sporadic. Rural areas typically have high density livestock housing and lack of advanced treatment systems for animal and human waste and wastewater. Animal waste from livestock production facilities is often applied to the land without prior treatment. Domestic wastewater is often treated on-site by septic systems without regular monitoring.

There is a potential risk of human exposure to waterborne contaminants such as human and zoonotic pathogens originating from manure, biosolids, and leaking septic systems in rural areas [13-15]. Livestock manure has been spread on the land as fertilizer and also for disposal. Manure and other wastes of various livestock often contain high concentrations of pathogens. Levels of pathogen in manure depend on the source animal, the animal's state of health, and how the manure was stored or treated before use. Non-point sources of contamination by manure include pastured animals, roaming wild animals, and leaching or runoff from agricultural areas. Point sources of manure contamination include animal feedlots, animal housing facilities, and manure storage areas, such as lagoons [16], resulting in soil and water contamination.

Biosolids (treated municipal wastewater sludge that meets standards for use as a fertilizer or soil conditioner); from large wastewater utilities in urban areas are often transported and applied to land in rural areas. Land application of biosolids provides agricultural benefits and presents a cost effective method for disposal of treated sludge following wastewater treatment; however, reuse of this product presents health concerns that must be addressed. Health concerns include pathogen transmission to food, contamination of ground water or surface water from field runoff, and build-up of heavy metals or organic contaminants $[17,18]$. Because biosolids may contain human pathogens $[13,19]$, exposure to biosolids has raised human health-related concerns. The microbial load of biosolids that are routinely applied on farm land varies depending on the type of sludge treatment and common sludge treatment processes do not completely inactivate pathogens.

\section{Characterization of Biosolids and Manure}

In 2004, a US national biosolids survey indicated that about 6.50 million tons of dry biosolids were produced in the US; and approximately $55 \%$ of the total was applied on land as soil amendment $[10,20]$. In 2006, the US EPA [21] estimated that more than 7.10 million tons of dry biosolids per year are produced in the US; about $50 \%$ of which are land applied. Land application of biosolids has increased 
since restrictions were placed on ocean dumping disposal. However, due to public concern over potential hazards, in some areas of the US land application of Class B biosolids has been banned. This is particularly true in California, where in many areas Class A land application has replaced Class B land application [22].

Biosolids contain organic matter and nutrients, and when applied to farmland can improve productivity and reduce the need for manufactured fertilizer inputs [23,24]. The main benefits of biosolids are through the supply of nitrogen, phosphorus, potassium, calcium, and magnesium, biosolids also supplying the essential plant micro nutrients (e.g., sulfur, manganese, zinc, copper, iron, molybdenum, and boron) [25]. Biosolids are a valuable source of nutrients although it contains lower N, $\mathrm{P}$, and $\mathrm{K}$ compared to commercial fertilizers, especially high-grade ones [26]. A study of nutrient levels in biosolids [27], with more than 240 samples collected and analyzed in Pennsylvania (aerobically digested, anaerobically digested, or alkali-treated) between 1993 and 1997 showed average N, P, and K contents of $4.74 \%, 2.27 \%$ and $0.31 \%$, respectively. Nutrient values of biosolids vary with sources of wastewater and wastewater treatment processes, in general compared to cattle manure, biosolids have lower P, the N:P ratio is around (3.1-3.4) [27,28], and have limited amount of K [29].

Even though biosolids are a beneficial soil amendment they may also pose a potential threat to the environment and pose risks to human health. There are potential hazards with land application since several contaminants can be present in biosolids including human pathogens [22,24,30,31]. Pathogens contained in biosolids include viruses, bacteria, and animal and human parasites (protozoa and helminthes), which may cause various human diseases and illnesses [24,32]. The characteristics and properties of biosolids vary depending on the quality and origin of sludge, along with the type of treatment processes [33-35]. Incomplete destruction, contamination from external sources, and changes in environmental factors during storage can lead to regrowth or reactivation of pathogens. Typical concentrations of some pathogens and indicators in biosolids are summarized in Table 1.

The rapid growth of concentrated animal feeding operations (CAFOS) has caused an increase in the amount of manure produced annually in US. There are approximately 450,000 CAFOs in the US including dairy, cattle, pig, and poultry farms. An estimated 450 million tons of wet weight manure or 90 million tons of dry solids manure are generated annually from about 92 million swine, 109 million cattle, 292 million turkeys, and 7.5 billion chickens in the US [36-38]. US EPA estimates that a single dairy cow produces approximately $55 \mathrm{~kg}$ /day of wet manure [39]. Livestock and poultry manure can provide large quantities of valuable nutrients for crop and pasture when applied to land as a fertilizer but most of this manure is applied untreated. Historically, the environmental impacts of animal manure were principally associated with nutrients [40]. Manure application rates are usually based on crop $\mathrm{N}$ requirement which greatly increases soil $\mathrm{P}$ levels because, the $\mathrm{N}$ : $\mathrm{P}$ ratios of manure (2:1 to 4:1) are significantly smaller than $\mathrm{N}$ : $\mathrm{P}$ uptake ratios $(6: 1$ to $8: 1)$ for most crops. The excess $\mathrm{P}$ and $\mathrm{N}$ (as $\mathrm{NO}_{3}$ ) from manure application can be transported in runoff or leached into the groundwater. Recently, however, other constituents such as naturally excreted hormones and pathogens have been of interest [41-43].

Although livestock manure is a good source of nutrients for crops and a natural way of recycling waste, raw manure is also a potential source of human pathogens if improperly stored and mishandled, or not managed correctly, fecal contamination from livestock manure handling and storage facilities is one of the most important sources of water microbiological pollution [21]. Animal manure depending on its origin can be a source of zoonotic pathogens such as Hepatitis E virus, Rotavirus A (some strains), 
Adenovirus (some strains), Aeromonashydrophila, Yersinia enterocolitica, Vibrio cholerae, Leptospira, Campylobacter jejuni, Escherichia coli 0157:H7, Salmonella spp., Listeria monocytogenes, Cryptosporidium parvum, and Giardia lamblia [44-53]. The concentration of some pathogens and indicators in manure are summarized in Table 2.

Table 1. Example pathogens and indicators in class B-biosolids.

\begin{tabular}{|c|c|c|c|}
\hline Organism & Detection Method & Concentration & Reference \\
\hline \multicolumn{4}{|c|}{ Pathogens } \\
\hline \multirow{3}{*}{ Salmonella sp. } & \multirow{3}{*}{ culture } & $1.2-3.2 \mathrm{MPNCU} / \mathrm{g}$ & {$[54]$} \\
\hline & & $0.487-0.954 \mathrm{MPN} / 4 \mathrm{~g}$ & [34] \\
\hline & & 40.1 MPN/4 g & {$[31]$} \\
\hline Cryptosporidium & Laser scanning cytometry & $4.3 / 10 \mathrm{~g}$ & {$[35]$} \\
\hline \multirow{4}{*}{ Adenoviruses } & \multirow{3}{*}{ qPCR } & $5 \times 10^{5}$ copies $/ g$ & {$[33]$} \\
\hline & & $7.5 \times 10^{5}$ copies $/ \mathrm{g}$ & [34] \\
\hline & & $1.59 \times 10^{4}$ copies $/ g$ & {$[55]$} \\
\hline & Cell culture & $480 \mathrm{MPN} / 4 \mathrm{~g}$ & {$[34]$} \\
\hline \multirow{2}{*}{$\begin{array}{c}\text { Human } \\
\text { polyomavirus }\end{array}$} & \multirow{2}{*}{ qPCR } & $8.05 \times 10^{2}$ copies $/ g$ & {$[55]$} \\
\hline & & $2.5 \times 10^{5}$ copies $/ g$ & {$[34]$} \\
\hline \multirow{9}{*}{ Enteroviruses } & \multirow{3}{*}{ qPCR } & $1.9 \times 10^{4}$ copies $/ g$ & {$[34]$} \\
\hline & & $4.8 \times 10^{3}$ copies $/ g$ & [54] \\
\hline & & $3.3 \times 10^{4}$ copies $/ g$ & {$[56]$} \\
\hline & \multirow{2}{*}{ RT-PCR } & $1.2 \times 10^{4} \mathrm{copies} / \mathrm{g}$ & {$[57]$} \\
\hline & & $1.0^{6} \times 10^{4}$ copies $/ g$ & {$[58]$} \\
\hline & \multirow{4}{*}{ Cell culture } & $480 \mathrm{MPN} / 4 \mathrm{~g}$ & [34] \\
\hline & & $38.2 \mathrm{MPNCU} / \mathrm{g}$ & {$[57]$} \\
\hline & & $9 \mathrm{MPNCU} / \mathrm{g}$ & {$[58]$} \\
\hline & & 15-80 MPNCU/g & {$[54]$} \\
\hline \multirow{2}{*}{ Noroviruses GI } & qPCR & $5 \times 10^{4}$ copies $/ g$ & {$[34]$} \\
\hline & Cell culture & $480 \mathrm{MPN} / 4 \mathrm{~g}$ & {$[34]$} \\
\hline \multirow{2}{*}{ Noroviruses GII } & qPCR & $1.5 \times 10^{5}$ copies $/ g$ & {$[34]$} \\
\hline & Cell culture & $480 \mathrm{MPN} / 4 \mathrm{~g}$ & {$[34]$} \\
\hline \multicolumn{4}{|c|}{ Indicators } \\
\hline \multirow{2}{*}{$\begin{array}{c}\text { Somatic } \\
\text { coliphages }\end{array}$} & \multirow{2}{*}{ Cell culture } & $5.5 \times 10^{2} \mathrm{PFU} / 10 \mathrm{~g}$ & {$[35]$} \\
\hline & & $2.09 \times 10^{5} \mathrm{PFU} / 4 \mathrm{~g}$ & {$[31]$} \\
\hline Total coliform & Culture & $7.64 \times 10^{5} \mathrm{MPN} / 4 \mathrm{~g}$ & {$[31]$} \\
\hline \multirow{2}{*}{ Enterococci } & \multirow{2}{*}{ Culture } & $7.2 \times 10^{5}-2.6 \times 10^{6} \mathrm{MPN} / \mathrm{g}$ & {$[54]$} \\
\hline & & $6.4 \times 10^{5} \mathrm{MPN} / \mathrm{g}$ & {$[56]$} \\
\hline \multirow{3}{*}{ E. coli } & \multirow{3}{*}{ Culture } & $4.4 \times 10^{5}-1.1 \times 10^{6} \mathrm{MPN} / \mathrm{g}$ & {$[54]$} \\
\hline & & $7.2 \times 10^{5} \mathrm{MPN} / \mathrm{g}$ & {$[56]$} \\
\hline & & $10^{4} \mathrm{MPN} / \mathrm{g}$ & {$[34]$} \\
\hline
\end{tabular}

Notes: qPCR-quantitative polymerase chain reaction; MPNCU-most probable number colony forming unit; RT-PCR-reverse transcription polymerase chain reaction; PFU-plaque forming unit. 
Table 2. Example pathogens and indicators in animal manure.

\begin{tabular}{ccc}
\hline Organism & Concentration & Reference \\
\hline & Pathogens & \\
\hline Salmonella sp. & $2.8 \times 10^{5} \mathrm{CFU} / 25 \mathrm{~g}$ & {$[59]$} \\
Listeria & $1.7 \times 10^{4} \mathrm{CFU} / \mathrm{g}$ & {$[59]$} \\
E. coli $\mathrm{O} 157: \mathrm{H} 7$ & $2.2 \times 10^{6} \mathrm{CFU} / \mathrm{g}$ & {$[60]$} \\
\hline & Indicators & \\
\hline Enterococci & $1.5 \times 10 \mathrm{MPN} / \mathrm{g}$ & {$[61]$} \\
E. coli & $10^{5}-10^{6} \mathrm{CFU} / \mathrm{g}$ & {$[61]$} \\
& $5.5 \times 10^{7} \mathrm{MPN} / \mathrm{g}$ & {$[59]$} \\
\hline
\end{tabular}

Notes: CFU-colony forming unit; MPN-most probable number.

In the US, the quantity of manure application as a soil amendment is 30 times higher than the biosolids application [21,23,37,38]. This is mostly due to high manure production and public acceptance of manure application practice for thousands of years [62]. In addition, most of the studies focus on the pathogens in biosolids, and there is lack of comparison studies for pathogens in manure [20,62].

In comparison, the benefits of biosolids as soil amendments are similar to those provided by animal manure, both provide important plant nutrients and organic matter. Animal manure contains more P than crops require if the application rate is based on $\mathrm{N}$ needs [40]. Most of the $\mathrm{N}$ in biosolids and manure is organic and becomes available to crops as it is mineralized. As a potential source of human pathogens public perception is that, biosolids pose higher risk to the public than animal manure. In fact, the risks associated with their use are not greater than the risks associated with untreated manure use. For example levels of E.coli indicator bacteria and Salmonella sp pathogens in manure are similar to biosolids (Tables 1 and 2). Overall quantitative data on total pathogen content and indicators in manure is limited comparing with biosolids.

\section{Association of Biosolids and Manure Application with Microbial Contamination of Surface and Groundwater}

Runoff from agricultural areas has been suggested as one of the major sources of nonpoint-source pollution [63]. Rainfall events may carry human pathogens in water runoff from contaminated sites to water bodies serving as recreational, irrigation or drinking water sources. The effects of nonpoint source pollutants on specific waters vary and may not always be fully assessed because they are not easy to identify. However, we know that nonpoint sources for biosolid and manure may have harmful effects on drinking water supplies, and recreation [64]. Nonpoint sources are difficult to control, and they pose a great threat to the integrity of the water bodies $[17,64]$.

Microbial source tracking (MST) methods have recently been used to help identify nonpoint sources, several microbial source tracking studies have pointed to the application of biosolids and manure. Lapen et al. [14], and Gottschall et al. [15] monitored tile- and ground- water quality for bacteria (Escherichia coli, enterococci, Clostridium perfringens) after land application of dewatered biosolids (using both spreading and surface injection application methods), and they found that there were no significant differences between using different methods of spreading biosolids, also they measured the concentration of the $E$. coli contamination in ground water. 
In May 2000 runoff from a field treated with cattle manure contaminated a groundwater supply with pathogenic bacteria $[65,66]$. In addition to human pathogenic E. coli and Campylobacter, other pathogens can also be present and survive in livestock manure. For example, human pathogenic protozoa, Giardia lamblia and Cryptosporidium parvum, can also be excreted by infected livestock and be transported in runoff events [67-69]. Microbial quality of runoff following land application of manure has been reported as an important source of microbial contamination of water bodies [18]. Studies involving fecal bacterial contamination in streams near dairy farms and cattle pastures [70,71], surface runoff from grazed pastures [72,73], and subsurface runoff from manure applied fields [74] demonstrated the ability of rain water runoff to transport bacteria from manure to surface water supplies. Rain events can also flush manure borne bacteria through the soil profile contaminating shallow groundwater [75] and springs and wells within the hydrological catchments of pastures [76].

Land-applied manure has been shown to quickly enter subsurface drains by preferential flow through macro pores [77,78]. Macro pores are large, continuous openings in the soil formed by plant roots, soil fauna, cracks, fissures and other natural phenomena. Shipitalo and Gibbs [34] reported that earthworm holes within $0.5 \mathrm{~m}$ of subsurface drains expedited the transmission of injected liquid to these drains. Soils under no-till crop management often have more continuous flow channels (macro pores) than tilled soils [79-81], and this may contribute to the rapid movement of injected manure to the subsurface drains.Bacterial contamination of drainage effluent was reported to be most likely in: (a) artificially drained, wet soils; (b) soils receiving high rates of liquid manure; and (c) soils that demonstrated preferential flow [82]. Several studies [77,83-86] reported that the application of liquid manure to drained fields resulted in elevated levels of nutrients and bacteria in the receiving waters compared to sites where liquid manure was not applied.

MST study on recreational water contamination in southeastern Lake Huron demonstrated that the dominant source of $E$. coli in lake water samples was agriculture, which supplied about $60 \%$ of the bacteria to the lake, whereas human sources provided only about three percent [87]. In addition, one study carried out on the South Shore Beach in Milwaukee concluded that the high E. coli levels were from local sources of pollution and were rarely affected by regional contamination events such as sewage overflows [88]. Another study by Verhougstraete and Rose [89], demonstrated that two sites in Lake Michigan have been impacted by bovine pollution, (67\%) samples were positive for the bacteroides cow marker. The bacteroides results indicate the major source of fecal contamination at both sites was cow manure.

Bacteria containing antibiotic resistance gene can also be released to the environment [90]. Although the levels of antibiotics in the environment are usually far below threshold levels to have inhibitory effects on bacterial populations, they still exert selective pressure on the development of antibiotic resistance in bacteria. The presence of antibiotic resistance genes in various environmental settings including river sediments, irrigation ditch water, dairy lagoon water, drinking water treatment plants and wastewater recycling plants has been confirmed [91,92]. Antibiotics and antibiotic-resistant bacteria can be released into streams and groundwater near concentrated animal feeding operation facilities [93-96]. In a study by Chee-Sanford et al. [94]. The presence of tetracycline resistance genes has been confirmed in waste lagoons on two swine farms, and in the groundwater underlying the two farms. These antibiotic-resistant genes may be transferred horizontally between bacterial species, even to animals and humans [97,98].

In addition, Munir and Xagoraraki [99] reported that 24 manure samples from three farms and 18 biosolids samples from seven different wastewater treatment plants across Michigan were analyzed for 
tetracycline and sulfonamide resistance genes (Tet-W, Tet-O, and Sul-I). They reported high concentrations of antibiotic resistance genes in manure and biosolids samples. The concentrations of antibiotic resistance genes in manure was significantly greater than in biosolids and the background soil samples had significantly less contaminations than the biosolids and manure.

\section{Risk Assessment}

Land application of biosolids and manure may cause human risks of infection for residents and occupational workers. Manure and biosolids, when applied to the land, may contribute to pathogens in surface water, air, soil and groundwater depending on extent of precipitation, aerosolization, and fate and transport of pathogens on surface soil, in subsurface soil media and in air (Figure 1). Human exposure to pathogens might occur from one or more of these exposure routes. Once infected, chances of illness and mortality depend on pathogen type and human susceptibility. The risk of human exposure to biosolids-associated pathogens has been assessed in several studies (Table 3). It is important to mention here that the reviewed studies are examples and do not represent a complete list of all published studies.

Figure 1. A schematic linking biosolids and manure application to human exposure.

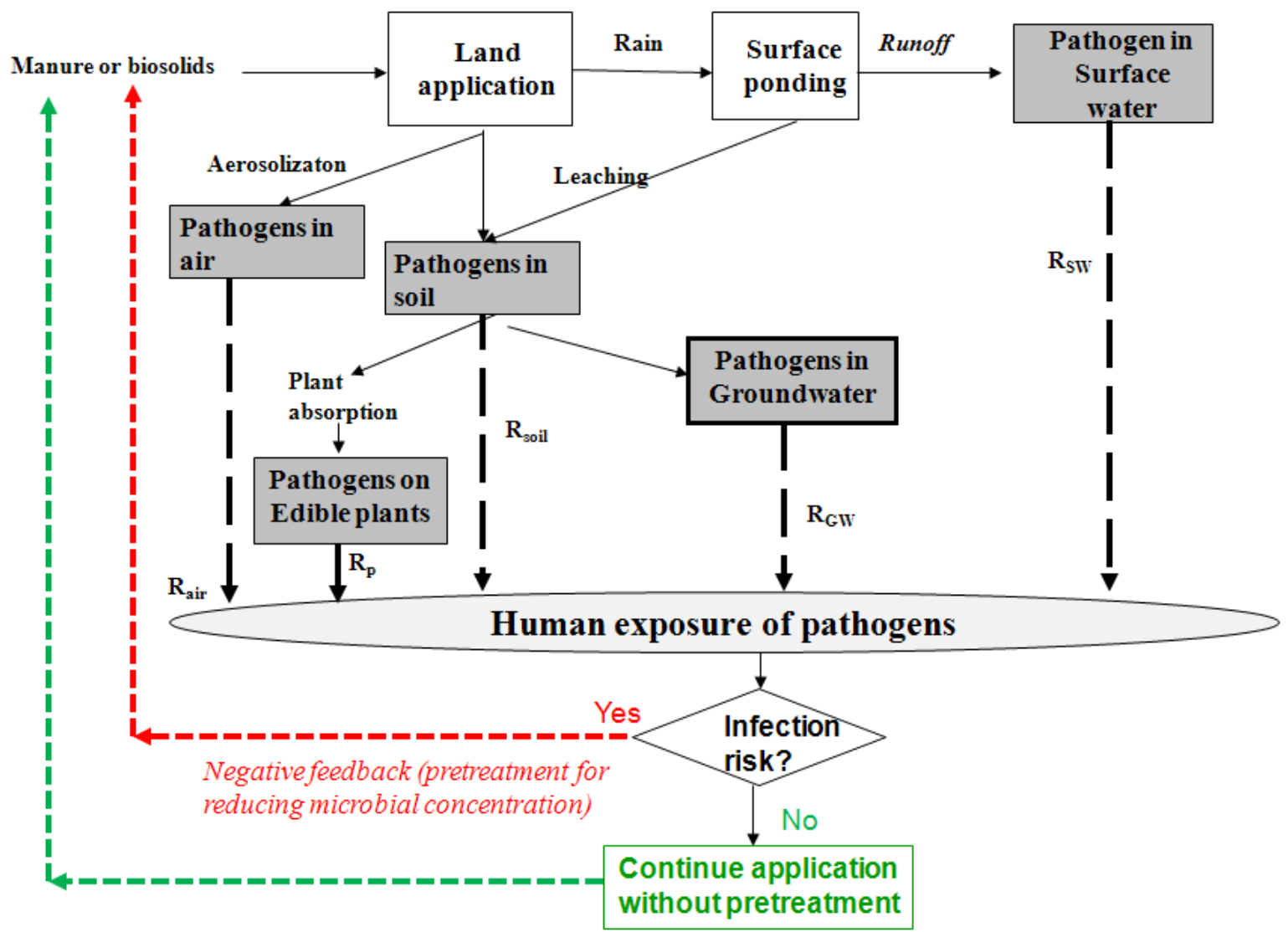

Notes: Five exposure routes: $\mathrm{R}_{\text {air }}$ (exposure through air route); $\mathrm{R}_{\mathrm{p}}$ (exposure through consumption of edible plants); $\mathrm{R}_{\text {soil }}$ (exposure through contact and ingestion of soil); $\mathrm{R}_{\mathrm{GW}}$ (exposure through ingestion of groundwater); and $\mathrm{R}_{\mathrm{SW}}$ (exposure through ingestion of surface water); SW (surface water); GW (groundwater). 
Table 3. Example studies focusing on risk assessment during land application activities of biosolids and/or manure.

\begin{tabular}{|c|c|c|c|c|}
\hline Ref. & Exposure Scenario & Microorganisms Type & Exposed Population & Findings/Risk Estimate \\
\hline \multicolumn{5}{|c|}{ Biosolids } \\
\hline$[100]$ & Ingestion of biosolids-contaminated soil & Rotavirus & $\begin{array}{c}\text { Residential population }(480 \mathrm{mg} / \mathrm{d} \text { soil } \\
\text { ingestion rate })\end{array}$ & $\begin{array}{l}\text { Risk of infection: } 7.8 \times 10^{-4} \text { (when mixed with soil); } \\
2.11 \times 10^{-1} \text { (without any mixing with soil) }\end{array}$ \\
\hline [101] & $\begin{array}{l}\text { Inhalation of indicator organisms from air during land } \\
\text { application activity }\end{array}$ & $\begin{array}{l}\text { Coliphage MS-2, } \\
\text { E. coli, coxsackievirus A21 }\end{array}$ & $\begin{array}{l}\text { Occupational workers (for } 1 \text { to } 8 \mathrm{~h} \text { of } \\
\text { exposure; } 0.1 \text { virus particles/g biosolids) }\end{array}$ & Risk of infection at $2 \mathrm{~m}: 1.64 \times 10^{-7}$ to $1.31 \times 10^{-6}$ \\
\hline [101] & $\begin{array}{l}\text { Inhalation of indicator organisms from air during land } \\
\text { application activity }\end{array}$ & $\begin{array}{l}\text { Coliphage MS-2, } \\
\text { E. coli , coxsackievirus A21 }\end{array}$ & $\begin{array}{l}\text { Residential population (for } 1 \text { to } 8 \mathrm{~h} \text { of } \\
\text { exposure; } 0.1 \text { virus particles/g biosolids) }\end{array}$ & Risk of infection at $30.5 \mathrm{~m}: 1.5 \times 10^{-8}$ to $1.2 \times 10^{-7}$ \\
\hline [102] & $\begin{array}{l}\text { Inhalation of indicator organisms from air during land } \\
\text { application of class B biosolids }\end{array}$ & Coliform bacteria, coliphages & Occupational workers & annual risk of infection: $7.8 \times 10^{-4}$ to $2.1 \times 10^{-2}$ \\
\hline [103] & $\begin{array}{c}\text { Direct contact of Class B biosolids and subsequent } \\
\text { ingestion (without incorporation in soil) }\end{array}$ & Ssalmonella & Residential (soil ingestion $=480 \mathrm{mg} / \mathrm{d}$ ) & Risk of infection $=5.7 \times 10^{-3}$ \\
\hline [103] & $\begin{array}{l}\text { Direct contact of Class B biosolids and subsequent } \\
\text { ingestion (with } 100 \text { times dilution with soil) }\end{array}$ & Salmonella & Residential (soil ingestion $=480 \mathrm{mg} / \mathrm{d}$ ) & Risk of infection $=5.510^{-5}$ \\
\hline [103] & $\begin{array}{l}\text { Direct contact with class A residuals following } \\
\text { regrowth of Salmonella } \\
\end{array}$ & Salmonella & Residential(soil ingestion $=480 \mathrm{mg} / \mathrm{d}$ ) & Risk of salmonella infection $=8 \times 10^{-1}$ \\
\hline [103] & $\begin{array}{l}\text { Direct contact with class A residuals following regrowth } \\
\text { of Salmonella (with } 100 \text { times dilution with soil) }\end{array}$ & Salmonella & Residential (soil ingestion $=480 \mathrm{mg} / \mathrm{d}$ ) & Risk of salmonella infection $=2.64 \times 10^{-1}$ \\
\hline [104] & Direct contact of Class B biosolids & $\begin{array}{c}\text { echovirus- } 12 \text {, enterovirus types } 68-71 \text {, adenoviruses, } \\
\text { rotaviruses, and noroviruses genotype-I }\end{array}$ & Residential population & Risk of infection: $4.45 \times 10^{-5}$ \\
\hline \multicolumn{5}{|c|}{ Manure } \\
\hline [105] & $\begin{array}{l}\text { Exposures from fomite, soil, crop, and aerosol } \\
\text { exposures from manure and biosolids }\end{array}$ & Bacteria and viruses & Occupational and residential population & $\begin{array}{l}\text { Greatest risk from direct consumption of contaminated } \\
\text { soil ; Greater bacterial risks from manure and greater } \\
\text { viral risks from biosolids }\end{array}$ \\
\hline [106] & Exposure of dairy wastewater & $\begin{array}{l}\text { Campylobacter jejuni, E.coliO157:H7, non-O157 } \\
\text { E.coli, Listeria monocytogenes, and Salmonella spp. }\end{array}$ & Residential & daytime risk is less than $10^{-6}$ at distance $>1 \mathrm{~km}$ \\
\hline [107] & Inhalation exposure during dairy manure application & $\begin{array}{c}\text { Enterococcusspp., E.coli, Salmonella } \\
\text { spp.,Campylobacter } \text { spp., E. coli } \mathrm{O} 157: \mathrm{H} 7\end{array}$ & Occupational (8h) & $\begin{array}{l}\text { Median risk of infection: } 1: 500(\text { at } 100 \mathrm{~m}) \text {, } \\
1: 100,000(\text { at } 1,000 \mathrm{~m})\end{array}$ \\
\hline
\end{tabular}


Risk of infection to residents and occupational workers during land application of biosolids depends on pathogen type, pathogen concentration in biosolids, pathogen concentration in air after aerosolization, pathogen concentration in soil, biosolids application methods and location of receptor from biosolids application activities [18,100-102,108]. For example, Gerba et al. [100] estimated risk of infection from enteric viruses during mixing of biosolids with soil for an assumed hypothetical exposure scenario. They reported that risk of daily infection from rotaviruses present in biosolids ranged from $7.8 \times 10^{-4}$ (when mixed with soil) to $2.11 \times 10^{-1}$ (without any mixing with soil) (enteric virus concentration in biosolids $=5.13 \mathrm{MPN} / 4 \mathrm{~g}$ biosolids; soil ingestion rate $=480 \mathrm{mg} / \mathrm{d}$ ). In addition, some studies conducted sampling of microbial indicators and pathogens to determine concentration of pathogens in air and water media for estimating risk of infection for different hypothetical exposure scenarios [18,101,102,108]. They observed microbial concentration with distances and sampling heights for different weather conditions (wind velocity and direction, relative humidity and temperature) to develop empirical fate and transport models. These studies have generally focused on estimating risk of microbial infection from one medium only [14,100-102,108]. However, different environmental compartments (i.e. air, surface water, soil, groundwater, vegetables) may be contaminated during land application of biosolids depending of methods of biosolids application (i.e., surface application, injection method). It is important to consider risk of infection from different environmental compartments to estimate the overall risk of infection during land application of biosolids.

To incorporate risk assessment and fate of biosolids-associated pathogens in different environmental media, Eisenberg [109] and Galada et al. [110] developed fate and transport models of pathogens after biosolids application using different application methods and predicted risks of infection for different exposure subpopulations. For example, the model "Spreadsheet Microbial Assessment of Risk: Tool for Biosolids "SMART Biosolids" included estimation of risk of infection due to more than 20 pathogens from surface water, air, groundwater, vegetables and soil during land application of biosolids [109]. In general, the following information is needed to run these comprehensive multi-compartment models: (a) weather-related information; (b) pathogenic concentration in biosolids; (c) biosolids application method; (d) decay of pathogens in different environmental media; (e) exposure- related information; and (f) dose-response information of different pathogens.

During land application of manure, some studies have conducted assessment of risk of pathogenic infection. Findings presented in Table 3. For example, Brooks et al., 2012 [105] compared risks of microbial infection during land application of manure and biosolids and found that risks of bacterial infection were higher during manure application activities and risks of viral infection were higher during biosolids land application activities. They further reported that risks of infection were higher due to land application of biosolids than land application of manure due to high infectivity of viruses. They also mentioned that risk estimates involved uncertainties due to lack of availability of concentration levels, field-specific inactivation rates of pathogens, and pathogens decay and regrowth rates. In another recent study by Jahne et al., 2014 [107] on risk assessment of bioaerosols from a manure application site indicated that peak risks (95th percentile values) were found to be very high (1:250) at $100 \mathrm{~m}$ distance from the source. During application of dairy wastewater, Dungan, 2014 [106] estimated inhalation risks of residents due to exposures of pathogens (Campylobacter jejuni, Escherichia coli O157:H7, non-O157 E.coli, Listeria monocytogenes, and Salmonella spp.) in bioaerosols and found that risks were higher near the source and infection, and depended on weather conditions and setback distance. They reported 
the need for data on: (a) aerosolization efficiency of pathogens during spray irrigation of wastewaters; (b) inactivation and deposition rates of airborne pathogens under various environmental conditions;

(c) inhalation transmission and dose-response of enteric pathogens in humans; and (d) exposure frequency and duration of affected populations.

A comparison of findings of risk assessment studies on pathogenic exposure from biosolids and manure indicated that risks of infection varied with setback distance, weather conditions (wind speed and direction, relative humidity, and temperature). Pathogen levels and extent of pathogen release from biosolids and manure during aerosolization and leaching due to rain events [68,111-114] was found to differ. Pathogen-related information needs to be obtained from fields and for conditions in which biosolids and/or manure are applied. Subsequently, pathogen-related fate and transport and risk models can be used.

\section{Best Management Practices for Biosolids to Protect Water Quality}

In 1993, the US EPA [115] established standards for land-applied biosolids under 40 CFR Part 503. Part 503 describes quantitative standards, management practices, operational standards, monitoring, recordkeeping, and reporting requirements for the use and disposal of biosolids. Individual states may develop additional guidelines so long as the state guidelines meet the minimum requirements of the federal Part 503 rule. Biosolids standards include limitations for metal and other compounds, pathogen reduction, vector requirements, best management practices, and include limitations for the land application of biosolids. Biosolids are physically, chemically and biologically treated to reduce pathogens to levels specified for Class $\mathrm{A}$ and $\mathrm{B}$ designations.

Class B biosolids (restricted use) are treated but still contain detectible levels of pathogens. Sludge to produce class B biosolids is treated using a "Processes to Significantly Reduce Pathogens" (PSRP), such as aerobic digestion, anaerobic digestion, air drying, and lime stabilization, which reduce but do not eliminate pathogens. Mesophilic anaerobic digestion (MAD) is the most prevalent treatment process for Class B biosolids in the US with a mean reduction in pathogen or indicator cultivability of $1 \log$ [116]. Class B biosolids must meet one of the three alternatives requirements: (1) Monitoring of indicator organisms based on fecal coliform; the geometric mean of the density of fecal coliform must be less than 2 million Colony Forming Units (CFU) or Most Probable Number (MPN) per gram of total dry solid in seven grab samples of sludge within one day, at the time of biosolids use or disposal; (2) Use of PSRP to significantly reduce pathogens; (3) Use of processes equivalent to PSRP, as determined by the permitting authority. Regulations for land application of Class B biosolids limit human exposure to pathogens by delaying harvesting post application, and prohibit the use of Class B biosolids on food crops eaten directly without processing. Class B biosolids can be applied on grain and forage crops, pastures, and grassland.

Class A biosolids (unrestricted use) contain no detectible levels of pathogens and low levels metals. Class A biosolids are treated by one of several "Processes to Further Reduce Pathogens" (PFRP), such as composting, pasteurization, drying or heat treatment, or advanced alkaline treatment, which reduce pathogens to below detectable levels. Class A classification is required for application onto public-use sites and certain food crops. This includes residential areas or home gardens, road banks, parks, golf courses, schools and other similar areas. Class A biosolids must meet one of the following bacteria 
limitations; fecal coliform is less than 1000 MPN per gram of total dry solid or Salmonella sp. bacteria density is less than 3 MPN per 4 grams of total dry solid. Class A biosolids pose minimal risk associated with use on edible food crops as a result of prior treatment that eliminates pathogens.

The Part 503 rule specifies upper limits for nine trace elements (Arsenic, Cadmium, Copper, Lead, Mercury, Molybdenum, Nickel, Selenium and Zinc) in sewage sludge to be land applied. Four options exist for meeting pollutant limits: The ceiling concentration limits (CCL), exceptional quality (EQ), cumulative pollutant loading rate (CPLR), and annual pollutant loading rate (APLR). Subpart D of the 503 rule addresses alternatives for limiting vectors such as rodents, birds and other organisms that could potentially spread disease by transporting pathogens from the application site. The goal of vector attraction reduction efforts is to either reduce the attractiveness of the biosolids to vectors by reducing organic matter (e.g., digestion, alkaline addition) or prevent vectors from coming into contact with the biosolids (e.g., subsurface injection or tillage incorporation within a short period of time after land application).

When biosolids are applied on agricultural land, they are applied at an agronomic rate to meet nitrogen requirements of the crop (CFR 40, Part 503.11) and prevent nitrogen loss to the environment. Individual states are allowed to expand the federal Part 503 rules to address state specific needs and concerns. In Michigan, Part 24 Rules of MDEQ [117] expands the Part 503 definition to include phosphorus and potassium in total nutrient management plans for crops grown at biosolids land application sites [117]. Biosolids cannot be applied to agricultural land if the phosphorus Bray P1 soil test is greater than $150 \mathrm{ppm}$ or $170 \mathrm{ppm}$ based on the Mehlich 3 soil test.

Specified management practices for the land application of biosolids prohibit application of bulk sewage sludge if the site is likely to adversely affect a threatened of endanger species, cannot be applied to flooded, frozen or snow-covered ground or within $10 \mathrm{~m}$ from water bodies (CFR 40, Part 503.14). The state of Michigan expanded the general restrictions in Part 24 Rules to include a separation distance of $600 \mathrm{~m}$ from municipal wells, $30 \mathrm{~m}$ from domestic wells, homes and commercial buildings, and $15 \mathrm{~m}$ from surface waters. A minimum separation distance of $0.75 \mathrm{~m}$ between the soil surface and groundwater is required when biosolids are applied. There are many regional variations in required set-back distances and other management practices to protect the environment and public health [118-122].

Because biosolids are frequently used as a source of crop nutrients there are restrictions on the timing of biosolids application and delay time between land application and crop harvest. Michigan Part 24 Rules prohibits the harvest of food crops for periods ranging from 14 to 38 months depending upon the crop following application and the method of application. A landowner cannot harvest food crops, feed crops, and fiber crops for 30 days after biosolids are applied. Livestock are not permitted to graze on land for 30 days after a biosolids application.

In conclusion, current biosolid treatment technologies that have been required by Part 503 Rule, with existing regulations and guidelines governing the use of biosolid as a soil amendment, are sufficient to protect human health and the environment [20]. To date there is no documented scientific evidence that the Part 503 Rule has failed to protect public health. 


\section{Best Management Practices for Livestock Manure to Protect Water Quality}

Runoff from the farmstead, pastures and fields where manure has been stored, deposited or applied can transport pathogens, sediment, organic solids, and nutrients to surface waters. Tillage and manure management practices that quickly move manure into the soil and root zone will protect water quality by recycling valuable crop nutrients and stabilizing potential contaminants by filtration, and sorption.

Best management practices (BMPs) are proven practical and affordable soil and water conservation and management approaches. BMPs vary from region-to-region and field-to-field because of variability in site-specific conditions and for flexibility to address local concerns. BMPs are determined through a collaborative effort of local stakeholders including farmers, extension educators, agribusiness professionals, regulatory agencies and technical service providers, and include cover crops, conservation tillage, buffer strips and set-backs along with soil and manure testing to implement management practices that prevent the loss of nutrients and biological contaminants to the environment.

All states have Right-to-Farm laws. For example, in Michigan, the Farm Act (P.A. 1981, No. 93) was adopted and amended in 1987 (P.A. 1987, No. 240) to protect the environment and to protect crop and livestock producers from nuisance suits if they are in compliance with Federal, state and local laws, and follow recommended manure management practices [123]. P.A. 1981, No. 93 authorized the development of Generally Accepted Agricultural and Management Practices (GAAMPs) for farms and farm operations. GAAMPs for Manure Management and Utilization are scientifically based, updated annually, and establish base-level management options for runoff control and wastewater management, odor management, construction design and management for manure storage and treatment facilities, and manure land application [123].

When manure is applied to cropland it is important to identify the fields and high-risk areas in fields where runoff is likely to occur. High risk areas include sloping ground, fields adjacent to ditches and waterways, bottom land that tends to flood in wet weather, tile drained land, and drained land with surface inlets. Vegetative filters, buffer strips and grass waterways have long been used to separate cropped or manure-applied land from nearby waterways. Widely used soil conservation practices that stabilize soil and prevent overland flow, runoff and soil erosion will help prevent manure contaminants from reaching waterways [124].

Conservation tillage leaves crop residue on the soil surface and is an effective way to reduce runoff and erosion. Low-disturbance aeration tillage is compatible with no-till cropping and creates an absorptive surface in untilled ground that inhibits overland flow by fracturing the soil, increasing surface roughness, improving infiltration, and conserving crop residues [125]. Tillage is generally helpful in disrupting preferential flow paths. Tillage disrupts macropores, delays manure movement, and can greatly decrease bacteria concentration in effluent [126]. Problems are likely when high rates of manure are applied and when manure is applied on wet ground or when tiles lines are flowing. Efforts to minimize problems must include low application rates [126,127]. Soil conservation practices that stabilize soil will help keep manure in the proper place. High risk soils typically are fine-textured soils with night crawler burrows. Sandy loams are lower risk.

Overland flow of manure contaminants can contribute to localized ponding and preferential flow to subsurface drains. Cover crops protect the soil from wind and water erosion, recycle nutrients, and improve soil structure and fertility. Cover crops create an effective barrier to overland flow and manure 
contamination of waterways [125]. When manure is applied to a bare soil surface, nutrients and other contaminants accumulate at the surface and increase the chance of nutrient and bacterial transport in runoff water. When manure is applied to a vegetative surface, the plant biomass and organic matter filters bacteria and nutrients.

Cover crops inhibit overland flow, filter sediment and organic materials, assimilate nutrients, and extract water from the soil thereby increasing water holding capacity. Cover crops can influence the persistence of indicator organisms and pathogens in the root zone. Work by Gagliardi and Karns [128] has shown greater persistence of $E$. coli $\mathrm{O} 157: \mathrm{H} 7$ on rye roots (47-96 d) and alfalfa roots (92 d) than in bare soil (25-41 d), but its persistence on crimson clover and hairy vetch roots were similar to bare soil. When manure slurry is applied to a vegetative surface the near-surface zone of high biomass and organic matter can enhance adsorption, straining and filtering of pathogens. Lim et al. [129] showed complete coliform removal of up to $2 \times 10^{7}$ colony forming units (cfu) $100 \mathrm{~mL}^{-1}$ in passing a $6.1 \mathrm{~m}$ tall fescue filter strip. Coyne et al. [130] reported $43 \%-74 \%$ removal of coliforms up to $10^{8} \mathrm{cfu} 100^{-1} \mathrm{~mL}$ in passing a $9 \mathrm{~m}$ mixed Kentucky bluegrass and tall fescue filter strip.

Technologies have been developed to treat manure nutrients and some of these technologies may also promote removal and degradation of pathogens such as physical treatments (separation of the solids and liquids in manure slurry by settling, filtration, screening, or drying), chemical treatments (addition of coagulants, such as lime, alum, and organic polymers to manure), and biological treatment (composting and anaerobic digestion).

\section{Conclusions and Recommendations}

A comprehensive management plan is needed to address problems of microbial water pollution in rural systems in a sustainable manner. There is a need to integrate the values and needs as well as the efforts of all stakeholders within a risk analysis framework. A key cornerstone of sustainable rural development is effective management of water and waste. Cooperation of farmers, township officials and individual homeowners is critical to achieve an effective plan. Awareness and education of responsible parties is a first step to an integrated plan and requires education of farmers, township officials, individual homeowners and water quality professionals regarding the benefits and risks associated with the use of biosolids and manure to help them make informed decisions about their choices. Interdisciplinary collaborations of scientists, engineers, and other professionals are essential.

Risk assessment frameworks for human exposure to contaminants in rural systems need to be evaluated. These comprehensive frameworks need to include identification of direct and indirect exposure pathways, pathogen data compilation, and risk assessment model development for land application of animal manure compared to biosolids. Quantitative data is a key component in the development of an effective risk assessment framework.

Pollution source tracking can help identify origins of pollution (manure or biosolids). Microbial source tracking tools can be coupled with geographical information system (GIS) data to help identify nonpoint sources in rural areas and minimize the human risks. The associations between bacterial communities and nutrient and chemical concentrations need to be assessed in order to determine if specific microbial community structure could be associated with specific types of chemical inputs and land uses. 
Another important issue is the identification of transport mechanisms of contaminants from manure and biosolids to groundwater and surface water. At this point simplistic safety guidelines, such as setback distances, are used for locating wells and waste application sites. More elaborate investigation based on physicochemical processes such as sorption, speciation, and biotic and abiotic transformations of contaminants in soil and water are needed. To achieve that, advanced source tracking laboratory techniques coupled with nested field sampling and process modeling is required.

Existing techniques for managing agricultural waste, such as land application in various crop systems, need to be re-evaluated based on their potential to remove and inactivate contaminants. Over the past decades, waste management focused on the effects of nutrients, especially $\mathrm{N}$ and $\mathrm{P}$, on water quality as the most important environmental concern. Microbes originating from biosolid and manure applications are often low on the priority for regulation and best management practices.In many cases, untreated manure may be applied in the setback areas where biosolids land application is prohibited; relatively few regulations govern land application of manure.Federal and state requirements regarding manure pathogens content are needed in order to preserve a water quality in rural areas

The critical issues that need further research and attention include risk assessment models and determination of exposure pathways, optimization and use of quantitative analytical methods, source tracking and transport mechanisms, and optimization of waste and water treatment. Investigation of alternative techniques for treatment of animal waste, such as anaerobic membrane bioreactors, as well as investigation of the feasibility of co-treatment of human and agricultural waste is of great interest.

\section{Acknowledgments}

The authors would like to thank Michigan State University, East Lansing (U.S.A.) and Indian Institute of Technology, Delhi (India).

\section{Conflicts of Interest}

The authors declare no conflict of interest.

\section{References}

1. Nicholson, F.; Groves, S.; Chambers, B. Pathogen survival during livestock manure storage and following land application. In ADAS Gleadthorpe Research Center, Meden Vale, Mansfield, Nottinghamshire NG20 9PF, UK; National Academy Press: Washington, DC, USA, 2004.

2. Meslin, F.X. Global Aspects of Emerging and Potential Zoonoses: A WHO Perspective. In Proceedings of the 1st International Conference on Emerging Zoonoses, Jerusalem, Israel, 24-28 November 1996.

3. Slifko, T.R.; Smith, H.V.; Rose, J.B. Emerging parasite zoonoses associated with water and food. Int. J. Parasitol. 2000, 30, 1379-1393.

4. Sobsey, M.D.; Khatib, L.A.; Hill, V.R.; Alocilja, E.; Pillai, S. Pathogens in Animal Wastes and the Impacts of Waste Management Practices on Their Survival, Transport and Fate. In White Paper, Midwest Plan Service; Iowa State University: Ames, IA, USA, 2001. 
5. Hubálek, Z. Emerging human infectious diseases: Anthroponoses, zoonoses, and sapronoses. Emerg. Infect. Dis. 2003, 9, 403-404.

6. Gannon, V.P. J.; Bolin, C.; Moe, C.L. Waterborne Zoonoses: Emerging Pathogens and Emerging Patterns of Infection. In Waterborne Zoonoses: Identification, Causes and Control; Cotruvo, J.A., Dufour, A., Rees, G., Bartram, J., Carr, R., Cliver, D.O., Craun, G.F., Fayer, R., Gannon, V.P.J., Eds.; WHO: London, UK, 2004.

7. Cliver, D.O.; Moe, C.L. Prospects of Waterborne Viral Zoonoses. In Waterborne Zoonoses: Identification, Causes and Control; Cotruvo, J.A., Dufour, A., Rees, G., Bartram, J., Carr, R., Cliver, D.O., Craun, G.F., Fayer, R., Gannon, V.P.J., Eds.; WHO: London, UK, 2004.

8. Palmer, S.; Brown, D.; Morgan, D. Early Qualitative Risk Assessment of the Emerging Zoonotic Potential of Animal Diseases. Br. Med. J. 2005, 331, 1256-1260.

9. Pourcher, A.M.; Morand, P.; Picard - Bonnaud, F.; Billaudel, S.; Monpoeho, S.; Federighi, M.; Moguedet, G. Decrease of enteric micro-organisms from rural sewage sludge during their composting in straw mixture. J. Appl. Microbiol. 2005, 99, 528-539.

10. Bofill-Mas, S.; Albinana-Gimenez, N.; Clemente-Casares, P.; Hundesa, A.; Rodriguez-Manzano, J.; Allard, A.; Calvo, M.; Girones, R. Quantitation and stabilityof human adenoviruses and polyomavirusJCPyV in wastewater matrices. Appl. Environ. Microbiol. 2006, 72, 7894-7896.

11. Pourcher, A.M.; Françoise, P.B.; Virginie, F.; Agnieszka, G.; Vasilica, S.; Gérard, M. Survival of fecal indicators and enteroviruses in soil after land-spreading of municipal sewage sludge. Appl. Soil Ecol. 2007, 35, 473-479.

12. Monpoeho, S.; Maul, A.; Bonnin, C.; Patria, L.; Ranarijaona, S.; Billaudel, S.; Ferré, V. Clearance of Human-Pathogenic Viruses from Sludge: Study of Four Stabilization Processes by Real-Time Reverse Transcription-PCR and Cell Culture. Appl. Environ. Microb. 2004, 70, 5434-5440.

13. Monpoeho, S.; Maula, A.; Mignotte-Cadiergues, B.; Schwartzbrod, L.; Billaudel, S.; Ferre, V. Best Viral Elution Method Available for Quantification of Enteroviruses in Sludge by Both Cell Culture and Reverse Transcription-PCR. Appl. Environ. Microbiol. 2001, 67, 2484-2488.

14. Gobernaa, M.; Podmirsega, S.; Waldhubera, S.; Knappa, B.; Garcíab, C.; Insama, H. Pathogenic bacteria and mineral $\mathrm{N}$ in soils following the land spreading of biogas digestates and fresh manure. Appl. Soil Ecol. 2011, 49, 18-25.

15. Kudva, I.T.; Blanch, K.; Hovde, C.J. Analysis of Escherichia coli O157: H7 survival in ovine or bovine manure and manure slurry. Appl. Environ. Microbiol. 1998, 64, 3166-3174.

16. Sinton, L.W.; Braithwaite, R.R.; Hall, C.H.; Mackenzie, M.L. Survival of indicator and pathogenic bacteria in bovine feces on pasture. Appl. Environ. Microbiol. 2007, 73, 7917-7925.

17. King, G.; Brooks, J.P.; Brown, S.; Gerba, C.; O’Connor, G.A.; Pepper, I.L. Land Application of Organic Residuals: Public Health Threat or Environmental Benefit; American Society for Microbiology: Washington, DC, USA, 2011.

18. Daniel, T.C.; Sharpley, A.N.; Lemunyon, J.L. Agricultural phosphorus and eutrophication: A symposium overview. J. Environ. Qual. 1998, 27, 251-257.

19. Scott, T.M.; Rose, J.B.; Jenkins, T.M.; Farrah, S.R.; Lukasik, J. Microbial source tracking: Current methodology and future directions. Appl. Environ. Microbiol. 2002, 68, 5796-5803. 
20. Easterling, D.R.; Evans, J.L.; Groisman, P.Y.; Karl, T.R.; Kunkel, K.E.; Ambenje, P. Observed variability and trends in extreme climate events: A brief review. Bull. Am. Met. Soc. 2000, 81, 417-425.

21. Easterling, D.R.; Thomas, K.R.; Gallo, K.P. Observed climate variability and change of relevance to the biosphere. J. Geophys. Res. 2000, 105, 20101-20114.

22. Atherholt, T.B.; LeChevallier, M.W.; Norton, W.D.; Rosen, J.S. Effect of rainfall on Giardia and Crypto. J. Am. Water Works Assoc. 1998, 90, 66-80.

23. Tate, K.W.; Atwill, E.R.; George, M.R.; McDougald, N.K.; Larsen, R.E. Crytposporidium parvum transport from cattle fecal deposits on California rangelands. J. Range Manag. 2000, 53, 295-299.

24. Kistemann, T.; Claben, T.; Koch, C.; Dangendorf, F.; Fischeder, R.; Gebel, J.; Vacata, V.; Exner, M. Microbial load of drinking water reservoir tributaries during extreme rainfall and runoff. Appl. Environ. Microbiol. 2002, 68, 2188-2197.

25. Gary, H.; Johnson, S.; Ponce, S. Cattle grazing impact on surface water quality in a Colorado front range stream. J. Soil Water Conserv. 1983, 38, 124-128.

26. Niemi, R.M.; Niemi, J.S. Bacterial pollution of waters in pristine and agricultural lands. J. Environ. Qual. 1991, 20, 620-627.

27. Doran, J.W.; Linn, D.M. Bacteriological quality of runoff water from pastureland. Appl. Environ. Microbiol. 1979, 37, 985-991.

28. Jawson, M.D.; Elliott, L.F.; Saxton, K.E.; Fortier, D.H. The effect of cattle grazing on indicator bacteria in runoff from a Pacific Northwest watershed. J. Environ. Qual. 1982, 11, 621-627.

29. Culley, J.L.B.; Phillips, P.A. Bacteriological quality of surface and subsurface runoff from manuredsandy clay loamsoil. J. Environ. Qual. 1982, 11, 155-158.

30. McMurry, S.W.; Coyne, M.S.; Perfect, E. Fecal coliform transport through intact soil blocks amended with poultry manure. J. Environ. Qual. 1998, 27, 86-92.

31. Howell, J.M.; Coyne, M.S.; Cornelius, P.L. Effect of sediment particle size and temperature on fecal bacteria mortality rates and the fecal coliform/fecal streptococci ratio. J. Environ. Qual. 1996, 25, 1216-1220.

32. Fleming, R.J.; Bradshaw, S.H. Contamination of Subsurface Drainage Systems during Manure Spreading; ASAE Paper No. 92-2618; American Society of Agricultural Engineers: St. Joseph, MI, USA, 1992.

33. Shipitalo, M.J.; Gibbs, F. Potential of Earthworm Burrows to Transmit Injected Animal Waste to Tile Drains. Soil Sci. Soc. Am. J. 2000, 64, 2103-2109.

34. Shipitalo, M.J.; Protz, R. Comparison of morphology and porosity of a soil under conventional and zero tillage. Can. J. Soil Sci. 1987, 67, 445-456.

35. Drees, L.R.; Karathanasis, A.D.; Wilding, L.P.; Blevins, R.L. Micromorphological characteristics of long-term no-till and conventionally tilled soils. Soil Sci. Soc. Am. J. 1994, 58, 508-517.

36. Pagliai, M.; Raglione, M.; Panini, T.; Maletta, M.; La Marca, M. The structure of two alluvial soils in italy after 10 years of conventional and minimum tillage. Soil Tillage Res. 1995, 34, 209-223.

37. Geohring, L.D.; Van Es, H.M. Soil Hydrology and Liquid Manure Applications. In Proceedings of the Liquid Manure Application Systems Conference, Rochester, NY, USA, 1994; pp. 166-174.

38. Evans, M.R.; Owens, J.D. Factors affecting the concentration of fecal bacteria in land drainage water. J. Gen. Micro. 1972, 71, 477-485. 
39. Dean, D.M.; Foran, M.E. The effects of farm liquid waste applications on tile drainage. J. Soil Water Conser. 1992, 47, 368-369.

40. McLellan, J.E.; Fleming, R.J.; Bradshaw, S.H. Reducing Manure Output To Streams from Subsurface Drainage Systems; ASAE Paper No. 93-2010; American Society of Agricultural Engineers: St. Joseph, MI, USA, 1993.

41. Jamieson, R.C.; Gordon, R.J.; Sharples, K.E.; Stratton, G.W.; Madani, A. Movement and Persistence of Fecal Bacteria in Agricultural Soils and Subsurface Drainage Systems: A Review. Can. Biosyst. Engin. 2002, 44, 1-9.

42. Kon, T.; Weir, S.C.; Howell, E.T.; Lee, H.; Trevors, J.T. Repetitive element (REP)-polymerase chain reaction (PCR) analysis of Escherichia coli isolates from recreational waters of southeastern Lake Huron. Can. J. Microbial. 2009, 55, 269-276.

43. McLellan, S.L.; Salmore, A.K. Evidence for localized bacterial loading as the cause of chronic beach closings in a freshwater marina. Water Res. 2003, 37, 2700-2708.

44. Rose, J.B.; Verhougstrate, M. Investigation of Water Quality and Sources Associated with Buck Creek Watershed; Michigan State University: East Lansing, MI, USA, 18 September 2008.

45. Sengelov, G.; Agerso, Y.; Halling-Sorensen, B.; Baloda, S.B.; Andersen, J.S.; Jensen, L.B. Bacterial antibiotic resistance levels in Danish farmland as a result of treatment with pig manure slurry. Environ. Intern. 2003, 28, 587-595.

46. Pei, R.; Kim, S.-C.; Carlson, K.; Pruden, A. Effect of River Landscape of the sediment concentrations of antibiotics and corresponding antibiotic resistance genes (ARG). Water Res. 2006, 40, 2427-2435.

47. Pruden, A.; Pei, R.; Storteboom, H.; Carlson, K. Antibiotic Resistance Genes as Emerging Contaminants: Studies in the Northern Colorado. Environ. Sci. Tech. 2006, 40, 7445-7450.

48. Batt, A.L.; Bruce, I.B.; Aga, D.S. Evaluating the vulnerability of surface waters to antibiotic contamination from varying wastewater treatment plant discharges. Environ. Pollut. 2006, 142, 295-302.

49. Chee-Sanford, J.C.; Aminov, R.I.; Krapac, I.J.; Garrigues-Jeanjean, N.; Mackie, R.I. Occurrence and Diversity of Tetracycline Resistance Genes in Lagoons and Groundwater Underlying Two Swine Production Facilities. Appl. Environ. Microbiol. 2001, 67, 1494-1502.

50. Sapkota, A.R.; Curriero, F.C.; Gibson, K.E.; Schwab, K.J. Antibiotic-resistant enterococci and fecal indicators in surface water and groundwater impacted by a concentration swine feeding operation. Environ. Health Perspect. 2007, 115, 1040-1045.

51. Song, W.; Huang, M.; Rumbeiha, W.; Li, H. Determination of amprolium, carbadox, monensin, and tylosin in surface water by liquid chromatography/tandem mass spectrometry. Rapid Commun. Mass. Spectrom. 2007, 21, 1944-1950.

52. Witte, W. Medical consequences of antibiotic use in agriculture. Science 1998, 279, 996-997.

53. Smith, K.E.; Besser, J.M.; Hedberg, C.W.; Leano, F.T.; Bender, J.B.; Wicklund, J.H.; Johnson, B.P.; Moore, K.A.; Osterholm, M.T. Quinolone-resistant campylobacter jejuni Infections in Minnesota, 1992-1998. N. Engl. J. Med. 1999, 340, 1525-1532.

54. Munir, M.; Xagoraraki, I. Levels of Antibiotic Resistance Genes in Manure, Biosolids, and Fertilized Soil. J. Environ. Qual. 2011, 40, 248-255. 
55. Gerba, C.P.; Pepper, I.L.; Whitehead, L.F., III. A risk assessment of emerging pathogens of concern in the land application of biosolids. Water Sci. Technol. 2002, 46, 225-230.

56. Brooks, J.P.; Tanner, B.D.; Gerba, C.P.; Haas, C.N.; Pepper, I.L. Estimation of bioaerosol risk of infection to residents adjacent to a land applied biosolids site using an empirically derived transport model. J. Appl. Microbiol. 2005, 98, 397-405.

57. Tanner, B.D.; Brooks, J.P.; Gerba, C.P.; Haas, C.N.; Josephson, K.L.; Pepper, I.L. Estimated occupational risk from bioaerosols generated during land application of class B biosolids. J. Environ. Qual. 2008, 37, 2311-2321.

58. Gerba, C.P.; Castro-del, C.; Brooks, J.O.; Pepper, I.L. Exposure and risk assessment of salmonella in recycled residuals. Water Sci. Technol. 2008, 57, 1061-1065.

59. Kumar, A.; Wong, K.; Xagoraraki, I. Effect of Detection Methods on Risk Estimates of Exposure to Biosolids-Associated Human Enteric Viruses. Risk Anal. 2012, 32, 916-929.

60. Brooks, J.P.; McLaughlin, M.R.; Gerba, C.P.; Pepper, I.L. Land application of manure and class B biosolids: An occupational and public quantitative microbial risk assessment. J. Environ. Qual. 2012, 41, 2009-2023.

61. Dungan, R.S. Estimation of Infectious Risks in Residential Populations Exposed to Airborne Pathogens During Center Pivot Irrigation of Dairy Wastewaters. Environ. Sci. Technol. 2014, 48, 5033-5042.

62. Jahne, M.A.; Rogers, S.W.; Holsen, T.M.; Grimberg, S.J. Quantitative microbial risk assessment of bioaerosols from a manure application site. Aerobiologia 2014, doi:10.1007/s10453-014-9348-0.

63. Low, S.Y.; Paez-Rubio, T.; Baertsch, C.; Kucharski, M.; Peccia, J. Off-site Exposure to Respirable Aerosols Produced during the Disk-incorporation of Class B Biosolids. J. Environ. Eng. 2007, 133, 987-994.

64. Eisenberg, J.N. Application of a Dynamic Model to Assess Microbial Health Risks Associated with Beneficial Uses of Biosolids; Water Environment Research Foundation: Alexandria, VA, USA, 2006; pp. 1-124.

65. Galada, H.G.; Gurian, P.L.; Joe, A.; Kumar, A.; Olson, B.; Olson, M.; Richter, E.; Teng, J.; Zhang, H.; Xagoraraki, I.; et al. Site Specific Risk Assessment Tool for Land Applied Biosolids; Water Environment Research Foundation: Alexandria, VA, USA, 2012.

66. Atwill, E.R.; Hou, L.; Karle, B.M.; Harter, T.; Tate, K.W.; Dahlgren, R.A. Transport of cryptosporidium parvum oocysts through vegetated buffer strips and estimated filtration efficiency. Appl. Environ. Microbiol. 2002, 68, 5517-5527.

67. Bradford, S.A.; Tadassa, Y.F.; Pachepsky, Y. Transport of Giardia and manure suspensions in saturated porous media. J. Environ. Qual. 2006, 35, 749-757.

68. Muirhead, R.W.; Collins, R.P.; Bremer, P.J. Numbers and transported state of Escherichia coli in runoff direct from fresh cowpats under simulated rainfall. J. Appl. Microbiol. 2006, 42, 83-87.

69. Chetochine, A.S.; Brusseau, M.L.; Gerba, C.P.; Pepper, I.L. Leaching of phage from class B biosolids and potential transport through soil. Appl. Environ. Microbiol. 2006, 72, 665-671.

70. US EPA. The Standards for the Use or Disposal of Sewage Sludge; Final 40 CFR Part 503 Rules; EPA 822/Z-93/001; US EPA: Washington, DC, USA, 1993.

71. Bibby, K.; Viau, E.; Peccia, J. Viral metagenome analysis to guide human pathogen monitoring in environmental samples. Lett. Appl. Microbiol. 2011, 52, 386-392. 
72. Michigan Department of Environmental Quality (MDEQ). Administrative Rules, Part 24, Land Application of Biosolids; Michigan Department of Environmental Quality, Surface Water Quality Division: Lansing, MI, USA, 1999.

73. Jacobs, L.W.; McCreary, D.S. Applying Biosolids to Land in Michigan; Extension Bulletin E-2780; Michigan State University: East Lansing, MI, USA, 2001.

74. Evanylo, G.K. Agricultural Land Application of Biosolids in Virginia; Publication 452-302; College of Agriculture and Life Sciences, Virginia Polytechnic Institute and State University: Blacksburg, VA, USA, 2009.

75. Eash, N.S.; McClurkan, J.; Burns, R.T. Best Management Practices (BMP's) for Land Application of Biosolids; University of Tennessee: Knoxiville, TN, USA, 1997.

76. Barbarick, K.A.; Ippolito, J.A. Nutrient assessment of a dry land wheat agroecosystem after 12 years of biosolids applications. Agron. J. 2007, 99, doi:10.2134/agronj2006.0221.

77. Arnold, K.; Dunn, J.; Carpenter, J.D. Best Management Practices for Biosolids Land Application; Extension Bulletin WQ426; University of Missouri Extension: Columbia, MO, USA, 1994.

78. Michigan Commission of Agriculture and Rural Development (MDARD). Generally Accepted Agricultural and Management Practices for Manure Management and Utilization; MDARD: Lansing, MI, USA, 2014.

79. Harrigan, T.M.; Northcott, W.; Rector, N.; Bolinger, D. Keeping Land-Applied Manure in the Root Zone: Part 1: Sediment and Contaminant Runoff; Extension Bulletin WO-1036; Michigan State University: East Lansing, MI, USA, 2007.

80. Harrigan, T.M.; Mutch, D.R.; Snapp, S.S. Slurry-Enriched Seeding of Biosuppressive Covers. Appl. Eng. Agric. 2006, 22, 827-834.

81. Harrigan, T.M. Manure on Tile-Drained Cropland. In Michigan Dairy Review; Michigan State University: East Lansing, MI, USA, 2005; Volume 10, pp. 10-12.

82. Harrigan, T.M.; Northcott, W.; Rector, N.; Bolinger, D. Keeping Land-Applied Manure in the Root Zone: Part 2: Tile-drained Land; Extension Bulletin WO-1037; Michigan State University: East Lansing, MI, USA, 2007.

83. Gagliardi, J.V.; Karns, J.S. Persistence of Escherichia coli O157:H7 in soil and on plant roots. Environ. Microbiol. 2002, 4, 89-96.

84. Lim, T.T.; Edwards, D.R.; Workman, S.R.; Larson, B.T.; Dunn, L. Vegetated filter strip removal of cattle manure constituents in runoff. Trans. ASAE 1998, 41, 1375-1381.

85. Craun M.F.; Craun G.F.; Calderon R.L. Beach M.J. Waterborne Outbreaks in the United States. J. Water Health 2006, 4, 19-30.

86. Craun, G.F. Waterborne disease outbreaks in the United States of America: Causes and prevention. World Health Stat. Q. 1992, 45, 192-199.

87. Craun, G.F.; Calderon, R.L.; Nwachuku, N. Causes of waterborne outbreaks reported in the United States. In Drinking Water and Infectious Disease: Establishing the Links; Hunter, P.R., Waite, M., Ronchi, E., Eds.; CRC Press: London, UK, 2003; pp. 1991-1998.

88. Lee, S.H.; Levy, D.A.; Craun, G.F.; Beach, M.J.; Calderon, R.L. Surveillance for waterborne-disease outbreaks-United States, 1999-2000. Morb. Mortal. Wkly. Rep. Surveill. Summ. 2002, 51, 1-47. 
89. Liang, J.L.; Dziuban, E.J.; Craun, G.C.; Hill, V.; Moore, M.R.; Gelting, R.J.; Calderon, R.L.; Beach, M.J.; Roy, S.L. Surveillance for waterborne disease and outbreaks associated with drinking water and water not intended for drinking-US, 2003-2004. MMWR Surveill. Summ. 2006, 55, 31-65.

90. US EPA. Prepublication of the Ground Water Rule Federal Register Notice; EPA-HQ-OW-2002-0061; FRL-RIN 2040-AA97; US EPA: Washington, DC, USA, 2006.

91. Hrudey, S.E.; Hrudey, E.J. Safe Drinking Water: Lessons from Recent Outbreaks in Affluent Nations; IWA-publishing: London, UK, 2004.

92. Curriero, F.C.; Patz, J.A.; Rose, J.B.; Lele, S. The association between extreme precipitation and waterborne disease outbreaks in the United States, 1948-1994. Am. J. Pub. Health 2001, 91, 1194-1201.

93. Hrudey, S.E.; Payment, P.; Huck, P.M.; Gillham, R.W.; Hrudey, E.J. A fatal waterborne disease epidemic in Walkerton, Ontario: Comparison with other waterborne outbreaks in the developed world. Water Sci. Technol. 2003, 47, 7-14.

94. National Research Council (NRC): Committee on Toxicants and Pathogens in Biosolids Applied to Land. In Biosolids Applied to Land: Advancing Standards and Practices; The National Academies Press: Washington, DC, USA, 2002; pp. 1-12.

95. Hoxie, N.J.; Davis, J.P.; Vergeront, J.M.; Nashold, R.D.; Blair, K.A. Cryptosporidiosis-Associated mortality following a massive waterborne outbreak in Milwaukee, Wisconsin. Am. J. Health 1997, 87, 2032-2035.

96. Craun, G.F.; Calderon, R.L.; Craun, M.F. Waterborne outbreaks caused by zoonotic pathogens in the USA. In Waterborne Zoonoses; IWA Publishing: London, UK, 2004; pp. 120-135.

97. Eisenberg, J.N.S.; Moore, K.; Soller, J.A.; Eisenberg, D.; Colford, J.M., Jr. Microbial risk assessment framework for exposure to amended sludge projects. Environ. Health Perspect. 2008, 116, 727-733.

98. Lapen, D.R.; Topp, E.; Edwards, M.; Sabourin, L.; Curnoe, W.; Gottschall, N.; Bolton, P.; Rahman, S.; Coelho, B.B.; Payne, M.; et al. Effect of liquid municipal biosolids application method on tile and groundwater quality. J. Environ. Qual. 2008, 37, 925-936.

99. Gottschall, N.; Edwards, M.; Topp, E.; Bolton, P.; Payne, M.; Curnoe, W.E.; Coelho, B.B.; Lapen, D.R. Nitrogen, phosphorous, and bacteria tile and groundwater quality following direct injection of dewatered municipal biosolids into soil. J. Environ. Qual. 2009, 38, 1066-1075.

100. Venglovsky, J.; Sasakova, N.; Vargova, M.; Pacajova, Z.; Placha, I.; Petrovsky, M.; Harichova, D. Evolution of temperature and chemical parameters during composting of the pig slurry solid fraction amended with natural zeolite. Bioresour. Tech. 2005, 96, 181-189.

101. Venglovsky, J.; Martinez, J.; Placha, I. Hygienic and ecological risks connected with utilization of animal manures and biosolids in agriculture. Livest. Sci. 2006, 102, 197-203.

102. Thurston-Enriquez, J.; Gilley, J.; Eghball, B. Microbial quality of runoff following land application of cattle manure and swine slurry. J. Water Health 2005, 3, 157-171.

103. Brooks, J.P.; Maxwell, S.L.; Rensing, C.; Gerba, C.P.; Pepper, I.L. Occurrence of antibiotic-resistant bacteria and endotoxin associated with the land application of biosolids. Can. J. Microbiol. 2007, $53,616-622$.

104. North East Biosolids and Residuals Association (NEBRA). A National Biosolids Regulation, Quality, End Use, and Disposal Survey; NEBRA: Tamworth, NH, USA, 2007. 
105. U.S. Environmental Protection Agency. Emerging Technologies for Biosolid Management; EPA 832-R-06-005; U.S. Environmental Protection Agency: Washington, DC, USA, 2006.

106. Pepper, I.L.; Brooks, J.P.; Gerba, C.P. Pathogens in biosolids. Adv. Agron. 2006, 90, 1-41.

107. Lyberatos, G.; Sklivaniotis, M.; Angelakis, A.N. Management of Biosolids in EUREAU Countries. Fresenius Environ. Bull. 2011, 20, 2489-2495.

108. Singh, R.P.; Agrawal, M. Potential benefits and risks of land application of sewage sludge. Waste Manag. 2008, 28, 347-358.

109. Lu, Q.; He, Z.L.; Stoffella, P.J. Land application of biosolids in the USA: A review. Appl. Environ. Soil Sci. 2012, doi:10.1155/2012/201462.

110. United Nations Industrial Development Organization (UNIDO); International Fertilizer Development Center (IFDC). Fertilizer Manual, 3rd ed.; Kluwer Academic Press: Norwell, MA, USA, 1998.

111. Stehouwer, R.C.; Wolf, A.M.; Doty, W.T. Chemical monitoring of sewage sludge in Pennsylvania: Variability and application uncertainty. J. Environ. Qual. 2000, 29, 1686-1695.

112. Shepherd, M.A.; Withers, P.J. Phosphorus leaching from liquid digested sewage sludge applied to sandy soils. J. Agric. Sci. 2001, 136, 433-441.

113. He, Z.L.; Alva, A.K.; Calvert, D.V.; Li, Y.C.; Stoffella, P.J.; Banks, D.J. Nutrient availability and changes in microbial biomass of organic amendments during field incubation. Compost. Sci. Util. 2000, 8, 293-302.

114. Hue, N.V. Sewage sludge. In Soil Amendments and Environmental Quality; Lewis Publishers: Boca Raton, FL, USA, 1995; pp. 199-247.

115. Pepper, I.L.; Brooks, J.P.; Sinclair, R.G.; Gurian, P.L.; Gerba, C.P. Pathogens and indicators in United States Class B biosolids: National and historic distributions. J. Environ. Qual. 2010, 39, 2185-2190.

116. US EPA. Cyanobacteria and Cyanotoxins: Information for Drinking Water Systems; Fact Sheet EPA-810F11001; US EPA: Washington, DC, USA, 2012.

117. Viau, E.; Peccia, J. Survey of Wastewater Indicators and Human Pathogen Genomes in Biosolids Produced by Class A and Class B Stabilization Treatments. Appl. Environ. Microbiol. 2009, 75, 164-174.

118. Wong, K.; Onan, B.; Xagoraraki, I. Quantification of enteric viruses, indicators and salmonella in Class B anaerobic digested biosolids by culture and molecular methods. Appl. Environ. Microb. 2010, 76, 6441-6448.

119. Guzman, C.; Jofre, J.; Montemayor, M.; Lucena, F. Occurrence and levels of indicators and selected pathogens in different sludges and biosolids. J. Appl. Microbiol. 2007, 103, 2420-2429.

120. Animal Health Institute, 2002. Available online: http://www.ahi.org (accessed on 29 June 2014).

121. Burkholder, J.; Libra, B.; Weyer, P.; Heathcote, S.; Kolpin, D.; Thorne, P.S.; Wichman, M. Impacts of waste from concentrated animal feeding operations on water quality. Environ. Health Perspect. 2007, 115, 308-312.

122. Wilson, S.C. Hogwash! Why Industrial Animal Agriculture Is Not beyond the Scope of Clean Air Act Regulation. Pace Environ. L. Rev. 2007, 24, 439.

123. US EPA. Protocol for Developing Pathogen TMDLs; EPA 841-R-00-002; United States Environmental Protection Agency: Washington, DC, USA, 2001. 
124. Jongbloed, A.W.; Lenis, N.P. Environmental concerns about animal manure. J. Anim. Sci. 1998, 76, 2641-2648.

125. Hanselman, T.A.; Graetz, D.A.; Wilkie, A.C. Manure-borne estrogens as potential contaminants: A review. Environ. Sci. Technol. 2003, 37, 5471-5478.

126. Johnson, A.C.; Williams, R.J.; Matthiessen, P. The total potential steroid hormone contribution of farm animals to freshwaters: The United Kingdom as a case study. Sci. Total Environ. 2006, 362, $166-178$.

127. Gerba, C.P.; Smith, E.J. Sources of pathogenic microorganisms and their fate during land application of wastes. J. Environ. Qual. 2005, 34, 42-48.

128. Guan, T.Y.; Holley, R.A. Pathogen survival in swine manure environments and transmission of human enteric illness: A review. J. Environ. Qual. 2003, 32, 383-392.

129. Hutchinson, M.L.; Walters, L.D.; Avery, S.M.; Munro, F.; Moore, A. Analyses of livestock production, waste storage, and pathogen levels and prevalences in farm manures. Appl. Environ. Microb. 2005, 71, 1231-1236.

130. Coyne, M.S.; Gilfillen, R.A.; Rhodes, R.W.; Blevins, R.L. Soil and fecal coliform trapping by grass filter strips during simulated rain. J. Soil Water Conserv. 1995, 50, 405-408.

(C) 2014 by the authors; licensee MDPI, Basel, Switzerland. This article is an open access article distributed under the terms and conditions of the Creative Commons Attribution license (http://creativecommons.org/licenses/by/4.0/). 